\title{
Review: Formulasi dan Evaluasi Sediaan Oral Effervescent
}

Maratul Mahdiyyah ${ }^{1, *}$, Irma Melyani Puspitasari², Norisca Aliza Putriana ${ }^{3}$, Mas Rizky A.A Syamsunarno ${ }^{4}$

1Program Studi Sarjana Farmasi, Fakultas Farmasi, Universitas Padjadjaran, Indonesia

2Departemen Farmakologi dan Farmasi Klinik, Fakultas Farmasi Universitas Padjadjaran, Indonesia

${ }^{3}$ Departemen Farmasetika dan Teknologi Farmasi, Fakultas Farmasi, Universitas Padjadjaran Indonesia

${ }^{4}$ Departemen IImu Kedokteran Dasar, Fakultas Kedokteran Universitas Padjadjaran, Indonesia

*E-mail: maratul16001@mail.unpad.ac.id

(Submit 11/5/2020, Revisi 19/5/2020, Diterima 3/8/2020)

\begin{abstract}
Abstrak
Rute pemberian oral menjadi rute pemberian yang paling popular dan paling sering digunakan dalam pengobatan pasien. Namun, salah satu masalah yang sering ditemui pada pasien dalam melakukan terapi dengan rute pemberian oral adalah adanya tidak kepatuhan dalam mengkonsumsi obat. Rasa yang tidak enak serta kemampuan beberapa pasien terutama lansia dan anak kecil yang tidak dapat menelan tablet menjadi alasannya. Effervescent menjadi salah satu alternatif yang dapat digunakan dalam mengatasi masalah tersebut. Review ini akan menggambarkan beberapa formulasi dan evaluasi sediaan effervescent serta penerapannya dalam beberapa sistem pemberian obat terbaru. Pencarian literatur dilakukan menggunakan bantuan situs pencarian jurnal online Pubmed, dan ditemukan 21 artikel dari 265 artikel yang sesuai dengan kriteria inklusi. Dari 21 artikel ini, 16 diantaranya adalah formulasi tablet effervescent. Metode granulasi basah diketahui merupakan metode terbaik dalam formulasi effervescent karena dapat meningkatkan daya alir serta indeks kompresibilitasnya. Asam sitrat dan natrium karbonat menjadi kombinasi agen effervescent yang paling sering digunakan.
\end{abstract}

Kata Kunci: Effervescent, formulasi, granul, tablet

\section{Outline}

- Pendahuluan

- Metode

- Hasil dan Pembahasan

- Kesimpulan

- Daftar Pustaka

\section{Pendahuluan}

Rute pemberian oral menjadi sistem pemberian obat yang paling terkenal dan paling sering digunakan dalam terapi dikarenakan kemudahan administrasinya ${ }^{1}$. Tablet menjadi salah satu sediaan padat yang sering digunakan dalam sistem pemberian obat oral. Namun, salah satu masalah yang sering ditemui pada pasien dalam melakukan terapi dengan rute pemberian oral adalah adanya tidak kepatuhan dalam mengkonsumsi obat. 
Penyebab utama yang biasa terjadi adalah karena pasien tidak bisa atau kesusahan dalam menelan tablet konvensional karena beberapa obat ada yang memiliki ukuran tablet yang cukup besar. Rasa pahit yang dimiliki obat juga menjadi salah satu alasan lain sehingga pasien tidak mematuhi resep. Akibatnya sering terjadi insiden terapi yang tidak efektif ${ }^{2,3}$.

Sediaan effervescent kini sedang popular di pasaran selain sebagai terapi kuratif, effervescent juga digunakan sebagai pemeliharaan dan pencegahan seperti suplemen, minuman kesehatan, dan nutraseutikal lain yang tersedia dalam bentuk granul maupun tablet. Effervescent diketahui dapat bereaksi jika ditambahkan atau dilarutkan dalam air menghasilkan buih dan menyebabkan tablet atau granul larut dalam air tersebut ${ }^{4,5}$. Effervescent bisa menjadi salah satu solusi dalam menyelesaikan masalah yang ada. Hal ini disebabkan oleh larutan karbonat yang berbentuk buih tersebut dapat menutupi rasa pahit yang dimiliki obat, memberikan sensasi kesegaran saat diminum. Kombinasi antara dua bentuk sediaan yang dimiliki memberikan manfaat untuk tetap mempertahankan kualitas sediaan padat yakni stabilitas yang tinggi, portabilitas mudah, dan dosis yang akurat ${ }^{6-8}$. Selain itu juga jika dibandingkan dengan tablet konvensional, effervescent dapat meningkatkan kelarutan serta bioavailabilitas obat. effervescent juga dapat mengurangi akibat iritasi yang sering ditimbulkan pada tablet konvensional karena telah terdistribusi secara merata. Pada suplemen atau nutraseutikal lain, jika dibandingkan dengan tablet biasa, effervescent dapat meningkatkan pengambilan cairan sehingga dapat mengatasi dehidrasi ${ }^{9-11}$.

Effervescent merupakan sediaan yang mengandung campuran dari substansi asam dan basa karbonat yang dapat mereaksi cepat ketika bertemu dengan air dan menghasilkan buih-buih atau gelembung gas karbondioksida $\left(\mathrm{CO}_{2}\right)$. Hal ini terjadi karena adanya reaksi kimia yang terjadi antara substansi asam dan basa yang bertemu sehingga membentuk suatu garam natrium dan menghasilkan $\mathrm{CO}_{2}$ serta air. Namun reaksi ini hanya dapat terjadi jika paling tidak terdapat sedikit air dalam produk ${ }^{7}$. Artikel review ini akan menggambarkan beberapa formulasi dan evaluasi sediaan effervescent serta penerapannya dalam sistem penghantaran obat baru.

\section{Metode}

Studi literatur dilakukan menggunakan bantuan situs pencarian jurnal online Pubmed dengan kata kunci "Effervescent formulation". Pencarian detail sebagai berikut: ((“Effervescent formulation" [All Fields]) NOT ("topical")) NOT ("review"[Publication Type] OR "review"[All Fields]). Terdapat total 265 artikel pada awal pencarian. Artikel yang digunakan untuk studi literatur ini adalah artikel dengan rentang publikasi dari tahun 2010-2020. Kriteria inklusi artikel yang akan dijadikan bahan penelitian yakni yang mengandung kata kunci pencarian, merupakan penelitian eksperimental, mencantumkan metode formulasi effervescent, dan merupakan sediaan oral. Untuk artikel dengan bahasa non-english serta yang membahas tentang sediaan non effervescent, gastroretentive, floating tablet, sustained released, atau pulsatile drug dieksklusi dari pencarian. Sehingga terdapat 21 jurnal yang menjadi acuan dalam penulisan artikel ini. 


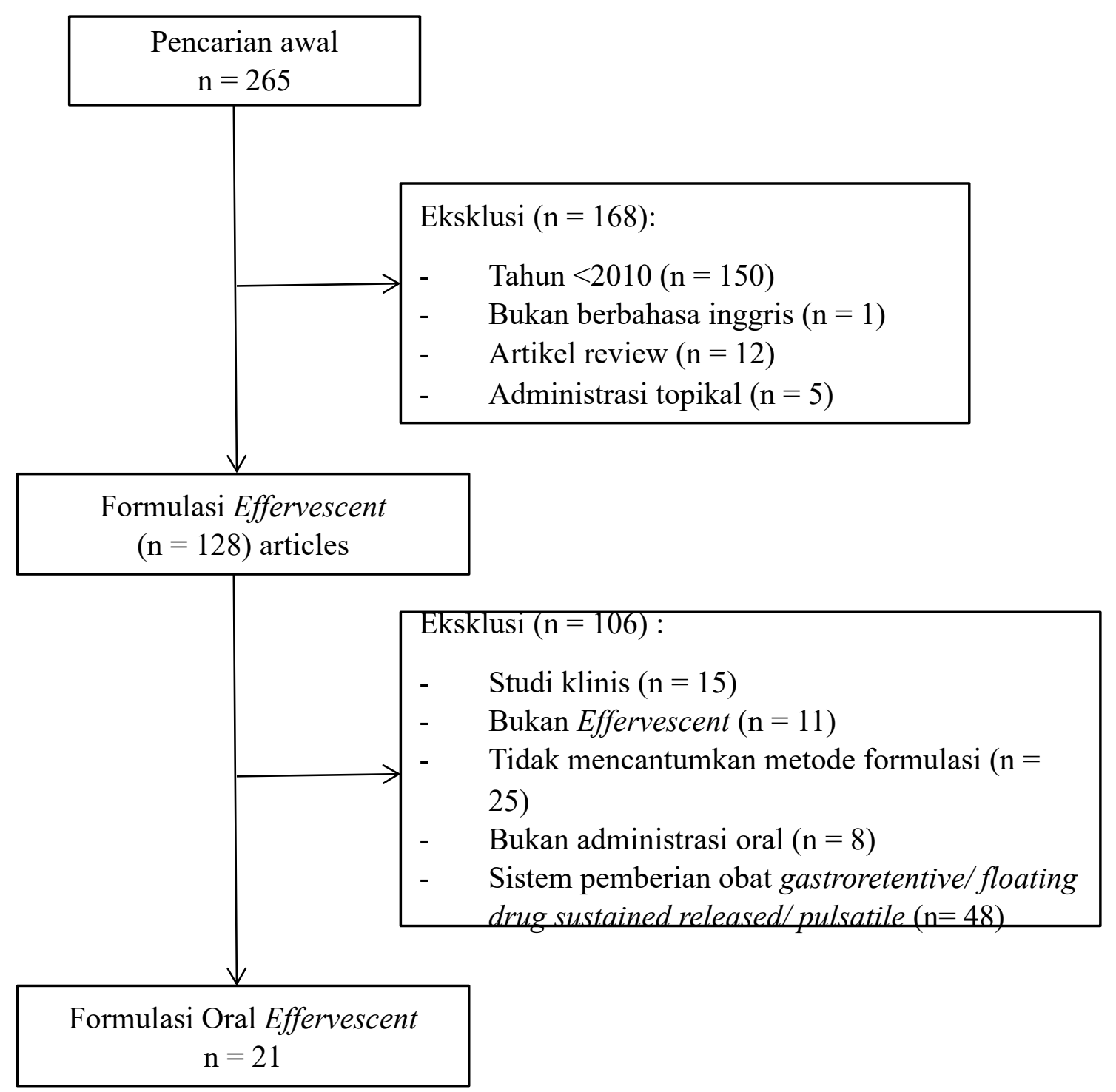

Gambar 1. Bagan Pencarian Literatur

Tabel 1 memperlihatkan 21 artikel yang membahas tentang formulasi dan evaluasi sediaan effervescent. Dari 21 artikel ini terdapat 16 artikel yang menggunakan sediaan tablet, 3 artikel dengan sediaan granul, 2 artikel dalam bentuk serbuk, dan 1 artikel dengan sediaan pelet.

\section{Hasil Dan Pembahasan}

Formulasi Tablet

Terdapat beberapa metode formulasi yang digunakan dalam pembuatan sediaan effervescent ini. Diantaranya metode granulasi basah, granulasi kering, serta kempa langsung dan fusi. Tabel 2 menjelaskan 16 artikel yang membahas mengenai formulasi sediaan tablet effervescent. Semua artikel ini menggunakan kempa langsung sebagai metode pembuatan tablet effervescent. Tetapi terdapat beberapa metode lain yang digunakan sebagai perbandingan, yakni 3 diantaranya dibangdingkan dengan metode fusi, dan 1 diantaranya dibandingkan dengan granulasi basah. 
Tabel 1. Daftar artikel yang digunakan

\begin{tabular}{|c|c|c|c|c|c|c|c|c|c|}
\hline No & Penulis & Tahun & Negara & $\begin{array}{c}\text { Jenis } \\
\text { Effervescent }\end{array}$ & $\begin{array}{c}\text { Komponen } \\
\text { Asam }\end{array}$ & $\begin{array}{c}\text { Komponen } \\
\text { Basa }\end{array}$ & $\begin{array}{c}\text { Komponen } \\
\text { Pengikat }\end{array}$ & $\begin{array}{c}\text { Komponen } \\
\text { Pengisi }\end{array}$ & $\begin{array}{c}\text { Komponen } \\
\text { Pemanis }\end{array}$ \\
\hline 1 & Patel et al ${ }^{12}$ & 2010 & India & Tablet & Asam Sitrat & $\begin{array}{l}\text { Natrium } \\
\text { Bikarbonat }\end{array}$ & Avicel 102 & Manitol & Aspartam \\
\hline 2 & $\begin{array}{l}\text { Shirsand et } \\
\text { al6 }\end{array}$ & 2010 & India & Tablet & $\begin{array}{l}\text { Asam sitrat } \\
\text { dan asam } \\
\text { tartrat }\end{array}$ & $\begin{array}{l}\text { Natrium } \\
\text { Bikarbonat }\end{array}$ & {$[-]$} & Manitol & Aspartam \\
\hline 3 & $\begin{array}{l}\text { Kamboj et } \\
\text { al10 }\end{array}$ & 2011 & India & Tablet & Asam Sitrat & $\begin{array}{l}\text { Natrium } \\
\text { Bikarbonat }\end{array}$ & {$[-]$} & {$[-]$} & Aspartam \\
\hline 4 & $\begin{array}{l}\text { Wening et } \\
\mathrm{al}^{27}\end{array}$ & 2012 & Jerman & $\begin{array}{l}\text { Serbuk } \\
\text { (Dibentuk } \\
\text { dalam solid } \\
\text { dosage pen) }\end{array}$ & Asam Tartrat & $\begin{array}{l}\text { Hidrogen } \\
\text { Karbonat }\end{array}$ & {$[-]$} & Manitol & {$[-]$} \\
\hline 5 & $\begin{array}{l}\text { Aslani et } \\
\text { al13 }\end{array}$ & 2013 & Iran & Tablet & Asam Sitrat & $\begin{array}{l}\text { Natrium } \\
\text { Bikarbonat }\end{array}$ & $\begin{array}{l}\text { PVP (hanya } \\
\text { untuk } \\
\text { metode } \\
\text { granulasi } \\
\text { basah) }\end{array}$ & {$[-]$} & Aspartam \\
\hline 6 & $\begin{array}{l}\text { Romero et } \\
\mathrm{al}^{29}\end{array}$ & 2013 & Spanyol & Granul & Asam tartrat & $\begin{array}{l}\text { Natrium } \\
\text { bikarbonat }\end{array}$ & $\begin{array}{l}\text { alkohol 96\% } \\
\text { (mengandu } \\
\text { ng 5\% } \\
\text { polivinilpirol } \\
\text { idon) }\end{array}$ & {$[-]$} & {$[-]$} \\
\hline 7 & $\begin{array}{l}\text { Aslani et } \\
\text { al }^{14}\end{array}$ & 2013 & Iran & Tablet & Asam Sitrat & $\begin{array}{l}\text { Natrium } \\
\text { Bikarbonat }\end{array}$ & {$[-]$} & {$[-]$} & $\begin{array}{l}\text { Manitol/ } \\
\text { Sorbitol/ } \\
\text { Sukrosa/ } \\
\text { Aspartam }\end{array}$ \\
\hline 8 & $\begin{array}{l}\text { Aslani et } \\
\text { al15 }\end{array}$ & 2014 & Iran & Tablet & Asam Sitrat & $\begin{array}{l}\text { Natrium } \\
\text { Bikarbonat }\end{array}$ & PVP & Mannitol & Aspartam \\
\hline 9 & Khan et al17 & 2014 & Pakistan & Tablet & Asam Sitrat & $\begin{array}{l}\text { Natrium } \\
\text { Bikarbonat }\end{array}$ & {$[-]$} & Tablettose & Aspartam \\
\hline 10 & Nazir et al30 & 2014 & Pakistan & Granul & Asam Sitrat & $\begin{array}{l}\text { Natrium } \\
\text { Bikarbonat }\end{array}$ & $\begin{array}{l}\text { PVP K-30 } \\
\text { dan } \\
\text { isopropil } \\
\text { alkohol }\end{array}$ & Mannitol & $\begin{array}{l}\text { Sakarin/ } \\
\text { aspartam/ } \\
\text { Erythritol }\end{array}$ \\
\hline 11 & $\begin{array}{l}\text { Elkhodairy } \\
\text { et } a^{18}\end{array}$ & 2014 & Egypt & Tablet & Asam Sitrat & $\begin{array}{l}\text { Natrium } \\
\text { Bikarbonat }\end{array}$ & {$[-]$} & $\begin{array}{l}\text { Ludipress } \\
\text { dan Manitol }\end{array}$ & {$[-]$} \\
\hline 12 & $\begin{array}{l}\text { Sarfraz et } \\
\text { al19 }\end{array}$ & 2015 & India & Tablet & Asam Sitrat & $\begin{array}{l}\text { Natrium } \\
\text { Bikarbonat }\end{array}$ & {$[-]$} & Laktosa & Sakarin \\
\hline 13 & Labib et al20 & 2015 & Egypt & Tablet & $\begin{array}{l}\text { Asam sitrat } \\
\text { dan asam } \\
\text { tartrat }\end{array}$ & $\begin{array}{l}\text { Natrium } \\
\text { Bikarbonat }\end{array}$ & Avicel 102 & Mannitol & {$[-]$} \\
\hline 14 & $\begin{array}{l}\text { Mohamme } \\
\text { d et al }{ }^{9}\end{array}$ & 2016 & Egypt & Tablet & $\begin{array}{l}\text { Asam sitrat } \\
\text { dan asam } \\
\text { tartrat }\end{array}$ & $\begin{array}{l}\text { Natrium } \\
\text { Bikarbonat }\end{array}$ & Manitol & Laktosa & Aspartam \\
\hline 15 & $\begin{array}{l}\text { Aslani et } \\
\mathrm{al}^{21}\end{array}$ & 2016 & Iran & Tablet & Asam Sitrat & $\begin{array}{l}\text { Natrium } \\
\text { Bikarbonat }\end{array}$ & PEG 6000 & Manitol & Aspartam \\
\hline 16 & $\begin{array}{l}\text { Karatzas et } \\
\mathrm{al}^{33}\end{array}$ & 2017 & Greece & Pelet & $\begin{array}{l}\text { Asam sitrat } \\
\text { dan asam } \\
\text { tartrat }\end{array}$ & $\begin{array}{l}\text { Natrium } \\
\text { bikarbonat }\end{array}$ & $\begin{array}{l}\text { Etanol dan } \\
\text { PEG }(1: 1)\end{array}$ & {$[-]$} & $\begin{array}{l}\text { sorbitol, } \\
\text { manitol, } \\
\text { xylitol }\end{array}$ \\
\hline 17 & $\begin{array}{l}\text { Venkateswa } \\
\text { rlu et } \text { al }^{22}\end{array}$ & 2017 & India & Tablet & Asam Tartrat & $\begin{array}{l}\text { Natrium } \\
\text { Bikarbonat }\end{array}$ & {$[-]$} & {$[-]$} & {$[-]$} \\
\hline 18 & Khan et $\mathrm{al}^{34}$ & 2017 & Pakistan & Tablet & Asam Tartrat & $\begin{array}{l}\text { Natrium } \\
\text { Bikarbonat }\end{array}$ & {$[-]$} & Laktosa & Sakarin \\
\hline 19 & $\begin{array}{l}\text { Tajmim et } \\
\mathrm{al}^{32}\end{array}$ & 2019 & USA & Serbuk & $\begin{array}{l}\text { Asam sitrat } \\
\text { dan asam } \\
\text { tartrat }\end{array}$ & $\begin{array}{l}\text { Natrium } \\
\text { Bikarbonat }\end{array}$ & {$[-]$} & Manitol & {$[-]$} \\
\hline 20 & Liu et $a^{31}$ & 2019 & China & Granul & Asam Sitrat & $\begin{array}{l}\text { Natrium } \\
\text { Bikarbonat }\end{array}$ & PEG 6000 & Laktosa & Aspartam \\
\hline 21 & Sun et $a^{23}$ & 2020 & China & Tablet & $\begin{array}{l}\text { Asam Sitrat } \\
\text { Monohidrat }\end{array}$ & $\begin{array}{l}\text { Natrium } \\
\text { Bikarbonat }\end{array}$ & {$[-]$} & $\begin{array}{l}\text { Manitol dan } \\
\text { Laktosa }\end{array}$ & {$[-]$} \\
\hline
\end{tabular}


Pada penelitian ini tidak dilakukan evaluasi pre-kompresi karena pada penelitian ini hanya melihat perbandingan effervescent dengan metode lain. Penelitian ini membandingkan metode effervescent dengan metode superdisintegrant dan sublimasi, dalam formulasinya berdasarkan tiga evaluasi berbeda. Setelah dilakukan evaluasi, ketiga metode memiliki nilai kekerasan yang sama yakni $2.5 \mathrm{~kg} / \mathrm{cm}^{3}$. Kemudian untuk kerapuhan metode effervescent memiliki nilai yang paling rendah yaitu $0.625 \%$, dan untuk waktu disintegrasi lebih cepat kedua setelah metode superdisintegrant yaitu 92 detik. Hal ini menunjukkan effervescent akan lebih cepat bereaksi jika dilarutkan atau ditambahkan dalam air $^{12}$.

Tabel 2. Formulasi Tablet Effervescent

\begin{tabular}{|c|c|c|c|c|c|c|}
\hline No. Artikel & Penulis & Tahun & Negara & Metode Formulasi & Evaluasi Pre-Kompresi & Evaluasi Post-Kompresi \\
\hline 1 & Patel et al & 2010 & India & Kempa Langsung & {$[-]$} & $\begin{array}{ll}- & \text { Uji kekerasan, } \\
- & \text { Kerapuhan, } \\
- & \text { Waktu disintegrasi }\end{array}$ \\
\hline 2 & Shirsand et al & 2010 & India & Kempa Langsung & {$[-]$} & $\begin{array}{ll}- & \text { kekerasan, } \\
- & \text { kerapuhan, } \\
- & \text { ketebalan, } \\
\text { - } & \text { keseragaman kandungan obat } \\
\text { - } & \text { waktu dispersi in vitro. }\end{array}$ \\
\hline 3 & Kamboj et al & 2011 & India & Kempa Langsung & $\begin{array}{l}\text { sudut istirahat } \\
\text { kerapatan curah, } \\
\text { kerapatan mampat, } \\
\text { indeks kompresibilitas, } \\
\text { rasio Hausner, dan } \\
\text { kekakuan. }\end{array}$ & $\begin{array}{l}\text { keseragaman berat, } \\
\text { uji kerapuhan, } \\
\text { kekerasan, } \\
\text { kadar obat, } \\
\text { waktu pembasahan, } \\
\text { rasio penyerapan air, } \\
\text { waktu hancur dan } \\
\text { disolusi in vitro }\end{array}$ \\
\hline 5 & Aslani et al & 2013 & Iran & $\begin{array}{l}\text { Fusi/ Kempa Langsung/ } \\
\text { Granulasi Basah }\end{array}$ & $\begin{array}{l}\text { ukuran partikel, } \\
\text { sudut istirahat, } \\
\text { indeks kompresibilitas, } \\
\text { dan } \\
\text { rasio Hausner. }\end{array}$ & $\begin{array}{l}\text { waktu efervesen, } \\
\text { nilai pH larutan, } \\
\text { kandungan } \mathrm{CO} 2\end{array}$ \\
\hline 7 & Aslani et al & 2013 & Iran & $\begin{array}{l}\text { Fusi dan Kempa } \\
\text { Langsung }\end{array}$ & $\begin{array}{ll}- & \text { sudut istirahat, } \\
\text { - } & \text { indeks kompresibilitas, } \\
\text { - } & \text { ukuran partikel rata-rata, } \\
\text { dan } \\
\text { - } & \text { rasio Hausner. }\end{array}$ & $\begin{array}{l}\text { variasi berat, } \\
\text { kekerasan, } \\
\text { kerapuhan, } \\
\text { kandungan obat, } \\
\text { waktu disolusi, } \\
\text { kandungan karbon dioksida, } \\
\text { waktu efervesensi, } \\
\text { nilai pH, } \\
\text { keseragaman kandungan, dan } \\
\text { kadar air. }\end{array}$ \\
\hline 8 & Aslani et al & 2014 & Iran & $\begin{array}{l}\text { Fusi dan Kempa } \\
\text { Langsung }\end{array}$ & $\begin{array}{l}\text { ukuran partikelnya, } \\
\text { kerapatan ruah, } \\
\text { kerapatan mampat, } \\
\text { indeks kompresibilitas, } \\
\text { rasio Hausner dan } \\
\text { sudut istirahat. }\end{array}$ & $\begin{array}{l}\text { variasi berat, } \\
\text { kerapuhan, } \\
\text { kekerasan, } \\
\text { pH larutan, } \\
\text { kandungan karbon dioksida (CO2), } \\
\text { waktu efervesensi, } \\
\text { ketebalan, } \\
\text { keseragaman kandungan, } \\
\text { kadar air, } \\
\text { kesetimbangan kadar air. }\end{array}$ \\
\hline 9 & Khan et al & 2014 & Pakistan & Kempa Langsung & $\begin{array}{l}\text { kerapatan mampat, } \\
\text { kerapatan longgar, } \\
\text { rasio Hausner, } \\
\text { Indeks Carr, } \\
\text { sudut istirahat }\end{array}$ & $\begin{array}{l}\text { waktu efervesensi, } \\
\text { kadar kelembapan, } \\
\text { kerapuhan, } \\
\text { kekuatan tekanan, } \\
\text { kekuatan hancur, } \\
\text { variasi berat }\end{array}$ \\
\hline 11 & Elkhodairy et al & 2014 & Egypt & Kempa Langsung & $\begin{array}{l}\text { sudut istirahat, } \\
\text { kerapatan mampat } \\
\text { kerapatan longgar, } \\
\text { indeks kompressibilitas, } \\
\text { rasio Hausner. }\end{array}$ & $\begin{array}{ll}\text { - } & \text { variasi berat, } \\
\text { - } & \text { tes kerapuhan, } \\
- & \text { kekerasan, } \\
- & \text { waktu pembasahan, } \\
- & \text { waktu disintegrasi, } \\
\text { - } & \text { waktu disolusi }\end{array}$ \\
\hline 12 & Sarfraz et al & 2015 & India & Granulasi Kering & $\begin{array}{ll}- & \text { kerapatan longgar, } \\
- & \text { kerapatan mampat, } \\
- & \text { sudut istirahat, } \\
- & \text { indeks kompresibilitas } \\
\text { Carr, } \\
\text { - } & \text { rasio Hausner. }\end{array}$ & $\begin{array}{ll}- & \text { uji kekerasan, } \\
- & \text { ketebalan dan diameter, } \\
- & \text { variasi berat, } \\
- & \text { kerapuhan, } \\
- & \text { waktu hancur, } \\
- & \text { studi disolusi, } \\
- & \text { waktu basah, } \\
- & \text { volume basah, } \\
- & \text { rasio penyerapan air, } \\
- & \text { waktu disintegrasi yang } \\
& \text { dimodifikasi, } \\
- & \text { keseragaman isi } \\
- & \text { stabilitas. }\end{array}$ \\
\hline
\end{tabular}


Tabel 2. Formulasi Tablet Effervescent (sambungan)

\begin{tabular}{|c|c|c|c|c|c|c|}
\hline No. Artikel & Penulis & Tahun & Negara & Metode Formulasi & Evaluasi Pre-Kompresi & Evaluasi Post-Kompresi \\
\hline 13 & Labib et al & 2015 & Egypt & Kempa Langsung & $\begin{array}{l}\text { sudut istirahat, } \\
\text { uji kompressibilitas }\end{array}$ & $\begin{array}{l}\text { variasi berat, } \\
\text { uji ketebalan, } \\
\text { kekerasan dan diameter, } \\
\text { friabilitas, } \\
\text { kadar kelembapan, } \\
\text { waktu pembasahan, } \\
\text { waktu efervesen, } \\
\text { waktu disintegrasi, } \\
\text { kandungan } \mathrm{CO2} \text {, } \\
\text { nilai pH larutan }\end{array}$ \\
\hline 14 & Mohammed et al & 2016 & Egypt & Kempa Langsung & Indeks Carr & $\begin{array}{l}\text { waktu efervesensi } \\
\text { nilai pH larutan }\end{array}$ \\
\hline 15 & Aslani et al & 2016 & Iran & Kempa Langsung & $\begin{array}{l}\text { sudut istirahat, } \\
\text { indeks } \\
\text { kompressibilitas, } \\
\text { rasio Hausner. }\end{array}$ & $\begin{array}{l}\text { variasi berat, } \\
\text { kerapuhan, } \\
\text { ketebalan, } \\
\text { kekerasan, } \\
\text { keseragaman kandungan, } \\
\text { waktu disintegrasi, } \\
\text { waktu disolusi }\end{array}$ \\
\hline 17 & $\begin{array}{l}\text { Venkateswarlu et } \\
\text { al }\end{array}$ & 2017 & India & Kempa Langsung & {$[-]$} & $\begin{array}{l}\text { Waktu pembasahan } \\
\text { Rasio penyerapan air }\end{array}$ \\
\hline 18 & Khan et al & 2017 & Pakistan & Kempa Langsung & $\begin{array}{l}\text { sudut istirahat, } \\
\text { kerapatan longgar, } \\
\text { kerapatan mampat, } \\
\text { indeks kompresibilitas } \\
\text { Carr, dan } \\
\text { rasio hausner. }\end{array}$ & $\begin{array}{l}\text { variasi berat, } \\
\text { uji ketebalan dan diameter } \\
\text { kekerasan, } \\
\text { friabilitas, } \\
\text { kadar kelembapan, } \\
\text { waktu pembasahan, } \\
\text { waktu disolusi, } \\
\text { waktu disintegrasi, } \\
\text { uji keseragaman kandungan, } \\
\text { nilai pH larutan }\end{array}$ \\
\hline 21 & Sun et al & 2020 & China & Kempa Langsung & $\begin{array}{l}\text { sifat alir } \\
\text { kadar air }\end{array}$ & $\begin{array}{ll}- & \text { kekuatan tekanan, } \\
- & \text { waktu disintegrasi, } \\
\text { - } & \text { pH larutan, } \\
\text { - } & \text { konsentrasi optimal agen efervesen } \\
\text { dalam tablet }\end{array}$ \\
\hline
\end{tabular}

Penelitian Patel di tahun 2010 menggunakan metode kempa langsung dengan penambahan agen pengikat yakni Avicel 102, serta asam sitrat dan natrium bikarbonat sebagai agen effervescent dalam pembuatan tablet larut dalam mulut cinnarizine. Berbeda dari tablet effervescent pada umumnya, penelitian ini membuat tablet larut dalam mulut. Dimana tablet ini akan hancur atau larut dalam saliva tanpa perlu menggunakan air. Pada penelitian ini tidak dilakukan evaluasi pre-kompresi karena pada penelitian ini hanya melihat perbandingan effervescent dengan metode lain. Penelitian ini membandingkan metode effervescent dengan metode superdisintegrant dan sublimasi, dalam formulasinya berdasarkan tiga evaluasi berbeda. Setelah dilakukan evaluasi, ketiga metode memiliki nilai kekerasan yang sama yakni $2.5 \mathrm{~kg} / \mathrm{cm}^{3}$. Kemudian untuk kerapuhan metode effervescent memiliki nilai yang paling rendah yaitu $0.625 \%$, dan untuk waktu disintegrasi lebih cepat kedua setelah metode superdisintegrant yaitu 92 detik. Hal ini menunjukkan effervescent akan lebih cepat bereaksi jika dilarutkan atau ditambahkan dalam air $^{12}$.

Penelitian Shirsand, menggunakan kombinasi asam sitrat dan asam tartrat sebagai substansi asam dan natrium karbonat sebagai substansi basa dalam pembuatan tablet effervescent lorazepam. Kombinasi substansi asam ini dapat mempermudah proses formulasi, dikarenakan jika hanya asam tunggal yang digunakan campuran yang dihasilkan akan terasa lebih lengket ataupun mudah menggumpal. Berdasarkan hasil waktu dispersinya yang berada pada rentang 0,1-3 detik, teknik effervescent diketahui dapat meningkatkan kelarutan ${ }^{6,7}$. 
Pada penelitian Kamboj dan Aslani, pembuatan tablet dengan metode kempa langsung menggunakan asam sitrat dan natrium karbonat sebagai agen effervescent. Namun pada penelitian Aslani, dilakukan juga metode lain sebagai perbandingan yakni metode fusi dan granulasi basah. Pada metode granulasi basah ditambahkan komponen pengikat yakni polivinilpirolidon (PVP). Dari ketiga metode ini diketahui metode granulasi basah memiliki hasil yang terbaik, karena ukuran granul yang lebih besar pada saat tahap sebelum dikempa jika dibandingkan serbuk pada metode kempa langsung dan granul pada metode fusi, metode granulasi basah menghasilkan kompresi dan keseragaman yang lebih baik ${ }^{13}$.

Dua penelitian Aslani lain melakukan formulasi tablet effervescent ranitidin dan amoxicillin dengan 2 metode berbeda yaitu metode fusi dan kempa langsung. Kedua penelitian ini membuktikan bahwa metode fusi memiliki hasil yang lebih baik berdasarkan daya alir dan kompresibilitasnya. Daya alir yang meningkat disebabkan oleh ukuran partikelnya yang lebih besar dibandingkan campuran serbuk effervescent pada metode kempa langsung. Hal ini mengakibatkan luas permukaannya yang mengecil, dan membuat gesekan antar partikel menurun. Nilai kompresibilitas granul yang lebih baik disebabkan oleh porositas internal yang meningkat dan gaya kohesi yang menurun lebih kecil dibandingkan serbuk ${ }^{14-16}$. Pada pembuatan tablet ranitidine ditambahkan empat pemanis yang berbeda yakni manitol, sorbitol, sukrosa, dan aspartam. Aspartam diketahui menjadi pemanis yang paling efektif dalam menutupi rasa pahit pada ranitidin ${ }^{14}$. Sedangkan pada pembuatan amoxicillin penambahan komponen pengikat yakni PVP diketahui meningkatkan kelarutan obat ${ }^{15}$.

Pada penelitian Khan dan Elkhodairy, metode kempa langsung digunakan dalam pembuatan tablet orodispersible domperidone dan flutamide. Kombinasi asam sitrat dan natrium bikarbonat digunakan sebagai agen effervescent. Dari hasil evaluasi keduanya yang berada pada rentang yang sesuai diketahui effervescent dapat meningkatkan bioavailabilitas obat ${ }^{17,18}$.

Penelitian Sarfraz di tahun 2015 menggunakan granulasi kering sebagai metode pembuatan tablet atenolol dan atorvastatin karena tidak menggunakan pengikat dalam formulasinya. Menggunakan asam sitrat dan natrium bikarbonat sebagai agen effervescent. Laktosa dipilih sebagai komponen pengisi, dan komponen pemanis menggunakan sakarin ${ }^{19}$.

Penelitian lain di Mesir pada tahun 2015 dan 2016 juga menggunakan metode kempa langsung dalam pembuatan tablet levotirizine dan risperidone. Kedua formulasi ini menggunakan kombinasi asam sitrat dan asam tartrat sebagai sumber asam dan natrium bikarbonat sebagai sumber basa. Pada penelitian di tahun 2015 Avicel 102 digunakan sebagai komponen pengikat, dan penelitian lain menggunakan manitol sebagai pengikat. Berdasarkan waktu effervescent nya tablet levotirizine dengan Avicel 102 lebih cepat yakni berkisar pada 15-22 detik. Sedangkan risperidone dengan Manitol sebagai pengikat memiliki waktu 28 detik $^{9,20}$. 
Penelitian Aslani di tahun 2016 yakni orodispersible montelukast juga menggunakan metode kempa langsung. Asam sitrat dan natrium bikarbonat digunakan sebagai agen effervescent. PEG 6000 digunakan sebagai pengikat, manitol sebagai pengisi, dan aspartame sebagai pemanis. Hasil evaluasi pre-kompresi serbuk yang dihasilkan memiliki daya alir yang cukup baik ${ }^{21}$.

Pada penelitian Venkateswarlu di India, metode kempa langsung digunakan dalam pembuatan clopidogrel. Asam tartrat dan natirum bikarbonat digunakan sebagai agen effervescent. berdasarkan evaluasi waktu dispersinya yakni 12 detik yang tergolong sangat baik 22 .

Penelitian yang sedikit berbeda dilakukan di tahun 2020, yakni pembuatan serbuk buah mangga yang diolah menggunakan metode kempa langsung menjadi tablet effervescent. Menggunakan asam sitrat sebagai sumber asam dan natrium bikarbonat untuk sumber basa, serta campuran manitol dan laktosa sebagai pengisi. Pada rasio agen effervescent di 40-45\%, memiliki waktu disintegrasi yang optimal yaitu 190 detik. Semakin meningkat rasio agen effervescent semakin meningkat pula jumlah asam sitratnya sehingga kekerasan dan gaya Tarik tablet meningkat. Hal ini disebabkan oleh struktur kristal asam sitrat dan partikel nya lebih besar dan keras dibanding serbuk yang lain. Karbondioksida yang dihasilkan dapat meningkatkan pelarutan serbuk dalam air, sementara peningkatan produksi buihnya dapat mencegah serbuk kontak dengan air sehingga dapat memperpanjang waktu disintegrasi. Pada rasio manitol:laktosa 1:8, hasilnya tablet memiliki waltu disintegrasi tercepat yakni 154 detik dengan gaya tarik $2,32 \mathrm{MPa}^{23,24}$. Hal ini bisa terjadi karena struktur laktosa anhidrat yang berbentuk menyerupai jarum dan sangat kasar, sehingga akan terihat strukturnya yang sangat berpori sehingga akan memiliki gaya tarik yang relatif lebih rendah. Seiring dengan meningkatnya rasio laktosa, partikel amorf kecil yang dimilikinya mampu mengisi ketidakteraturan permukaan, sehingga campuran serbuk menjadi sangat rapat dan akan cenderung memiliki kekerasan yang lebih besar yang berakibat memperpanjang proses disintegrasi ${ }^{25,26}$.

\section{Formulasi Granul dan Serbuk}

Umumnya dalam pembuatan granul lebih banyak digunakan metode granulasi basah dibandingkan dengan granulasi kering karena penambahan zat pengikat yang mampu meningkatkan daya alirnya. Pada tabel 3 ditunjukkan 5 artikel formulasi granul dan serbuk, dimana 3 diantaranya menggunakan metode granulasi basah, 1 diantaranya menggunakan granulasi kering serta terdapat metode baru khusus untuk sediaan tertentu yakni proses ekstrusi basah (wet extrusion process).

Penelitian terbaru di Jerman pada tahun 2012, membuat sediaan solid dosage pen dengan serbuk effervescent sebagai pengobatan individu. Menggunakan metode ekstrusi basah dalam prosesnya dimana campuran asam tartrat dan hidrogen karbonat sebagai agen effervescent dicampur dengan manitol dan zat aktif dengan penambahan etanol sebagai pelarut pada perbandingan 1:9. 
Semua campuran ini dimasukkan langsung ke dalam ekstruder untuk diekstrusi yang kemudian diperoleh untaian silinder untuk selanjutnya dipotong-potong. Berdasarkan Farmakopeia, formulasi effervescent harus dapat terdisntegrasi dalam waktu 5 menit di $200 \mathrm{ml}$ air. Pada penelitian potongan dosis dari sediaan mampu terdisintegrasi dalam waktu kurang dari 5 menit. Sediaan tersebut dapat terdisolusi sempurna dalam waktu 80 detik $^{27,28}$.

Tabel 3. Formulasi Granul/Serbuk Effervescent

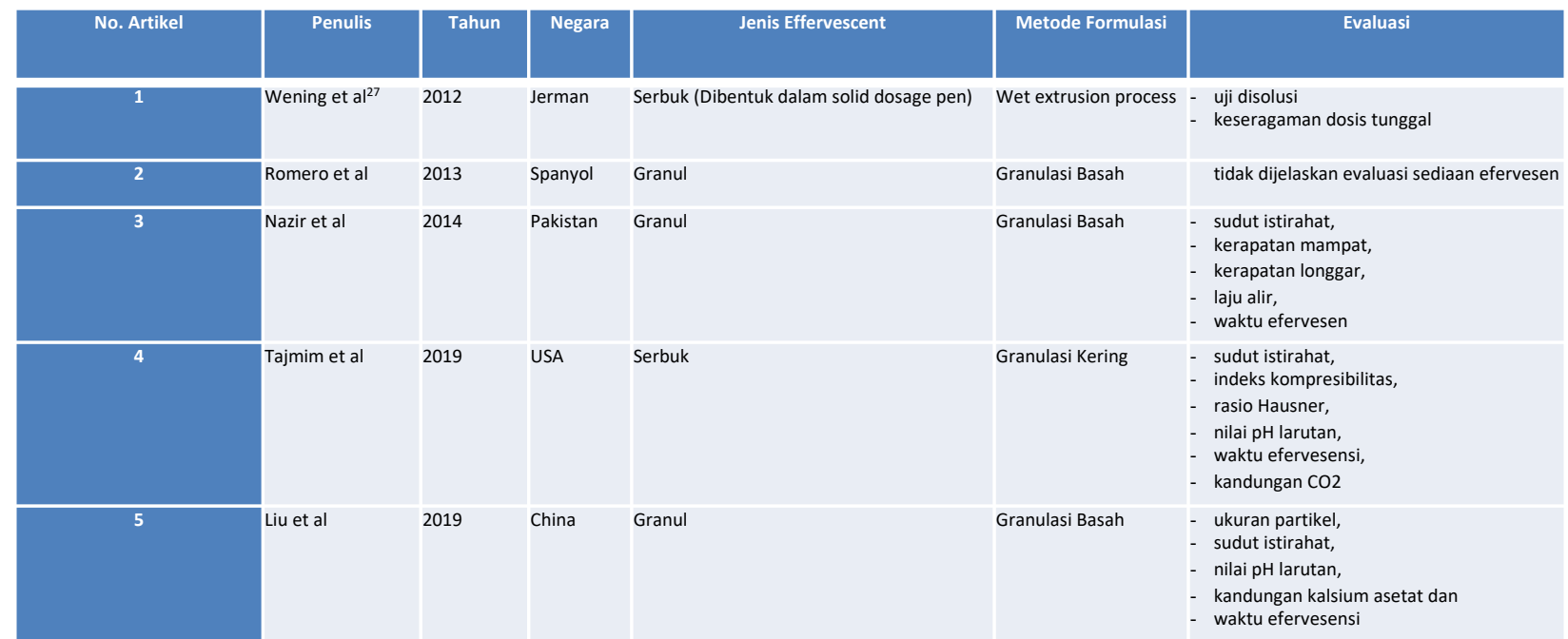

Penelitian di Spanyol pada tahun 2014 mengaplikasikan granul effervescent dengan menggunakan metode granulasi basah dalam pembuatan nutraseutikal mengandung sayuran kering. Penggunaan asam tartrat dan natrium bikarbonat sebagai agen effervescent serta alkohol 96\% (mengandung 5\% PVP) sebagai pengikat. Dari penelitian ini granul effervescent diketahui bisa menjadi salah satu pilihan bentuk sediaan lain selain serbuk dan granul biasa, dalam membuat nutraseutikal yang mengandung sayuran kering. Gas karbondioksida yang dihasilkan mampu menutupi rasa yang kurang enak di mulut ${ }^{29}$.

Penelitian lain di tahun 2014 dan 2019 di Jerman dan Cina menggunakan metode granulasi basah dalam pembuatan granul metformin dan kalsium asetat. Asam sitrat dan natrium bikarbonat digunakan sebagai agen effervescent, dengan agen pengikat yang berbeda. Pada granul metformin ditambahkan PVP K-30 dan isopropril alkohol sebagai pengikat sedangkan pada granul kalsium asetat menggunakan PEG 6000. Kedua penelitian ini menggunakan aspartam sebagai pemanis, namun pada penelitian granul metformin dibandingkan dengan beberapa pemanis lain yakni sakarin dan eritritol. Dari kedua penelitian ini dibuktikan bahwa aspartame dapat menjadi pemanis yang paling cocok dalam pembuatan granul effervescent ${ }^{30,31}$.

Penelitian di Amerika pada tahun 2019 membuat serbuk nutraseutikal (-)-Oleocanthal sebagai terapi untuk kanker payudara. Menggunakan kombinasi asam sitrat dan asam tartrat sebagai sumber asam dan natrium bikarbonat sebagai sumber basa serta manitol sebagai pengisi. Berdasarkan sudut istirahat, indeks kompresibilitas, dan rasio Hausner menunjukkan hasil daya alir yang sangat baik. Waktu effervescent yang dimiliki juga memenuhi syarat ${ }^{32}$. 
Formulasi Lainnya

Penelitian di Yunani pada tahun 2017 menggunakan teknis effervescent dalam pembuatan pellet. Kombinasi asam sitrat dan asam tartrat digunakan sebagai sumber asam serta natrium bikarbonat sebagai sumber basa. Dengan komponen pengikat etanol : PEG (1:1), dan pemanis yang digunakan adalah kombinasi sorbitol, manitol dan xylitol. Dari penelitian ini dibuktikan effervescent dapat meningkatkan kelarutan pellet dalam air $^{33}$.

\section{Kesimpulan}

Artikel ini merangkum beberapa formulasi dan evaluasi dari sediaan effervescent dalam bentuk serbuk, granul, tablet serta pellet dari 21 artikel yang didapat, 16 diantaranya menggunakan sediaan tablet effervescent. Metode kempa langsung menjadi pilihan terbanyak yang digunakan dalam formulasi tablet effervescent karena lebih mudah dan cepat. Perpaduan asam sitrat dan natrium bikarbonat sebagai agen effervescent dalam formulasi menjadi yang paling sering digunakan. Selain itu, aspartam menjadi pemanis yang paling sering digunakan dalam formulasi sediaan effervescent.

\section{Daftar pustaka}

1. Patel SG, Siddaiah M. Formulation and evaluation of Effervescent tablets: a review. J Drug Deliv Ther. 2018. doi:10.22270/jddt.v8i6.202

2. Seager $\mathrm{H}$. Drug-delivery products and the Zydis fast-dissolving dosage form. Journal of Pharmacy and Pharmacology. J Pharm Pharmacol. 1998;50((4)):375-382

3. Bailey CJ, Day C. Metformin: Its botanical background. Pract Diabetes Int. 2004. doi:10.1002/pdi.60

4. Agyilirah GA, Green M, duCret R, Banker GS. Evaluation of the gastric retention properties of a cross-linked polymer coated tablet versus those of a nondisintegrating tablet. Int J Pharm. 1991. doi:10.1016/0378-5173(91)90198-

5. Swarbrick J. Encyclopedia of Pharmaceutical Technology.; 2013. doi:10.1201/b1930

6. Shirsand SB, Suresh S, Jodhana LS, Swamy P V. Formulation design and optimization of fast disintegrating Lorazepam tablets by Effervescent method. Indian J Pharm Sci. 2010;72(4):431-436. doi:10.4103/0250-474X.7391

7. Ansel HC. Pengantar Bentuk Sediaan Farmasi Edisi IV.; 1989

8. Pharmacopeia B. British pharmacopeia. $\mathrm{Br}$ pharmacopeia. 1998. doi:10.3945/an.110.000117.3

9. Mohammed KAB, Ibrahim HK, Ghorab MM. Effervescent tablet formulation for enhanced patient compliance and the therapeutic effect of risperidone. Drug Deliv. 2016;23(1):297-306. doi:10.3109/10717544.2014.912693 
10. Kamboj M, Goyal S, Rakha P, Arora G, Dureja H, Nagpal M. Formulation and evaluation of metformin oro-dispersible tablets. Acta Pol Pharm. 2011;68(5):717723.

11. Discov JNB, Foldvari M. Nanopharmaceutics Innovations in Gene Therapy: Moving Towards Non-Viral and Non-Invasive Delivery Methods. J Nanomedine Biotherapeutic Discov. 2014;04(02). doi:10.4172/2155-983x.1000e135

12. Patel BP, Patel JK, Rajput GC, Thakor RS. Formulation and evaluation of mouth dissolving tablets of cinnarizine. Indian J Pharm Sci. 2010;72(4):522-525. doi:10.4103/0250-474X.73930

13. Aslani $A$, Fattahi F. Formulation, characterization and physicochemical evaluation of potassium citrate Effervescent tablets. Adv Pharm Bull. 2013;3(1):217-225. doi:10.5681/apb.2013.036

14. Aslani $A$, Jahangiri $H$. Formulation, characterization and physicochemical evaluation of ranitidine Effervescent tablets. Adv Pharm Bull. 2013;3(2):315-322. doi:10.5681/apb.2013.051

15. Aslani A, Sharifian T. Formulation, characterization and physicochemical evaluation of amoxicillin Effervescent tablets. Adv Biomed Res. 2014;3:209. doi:10.4103/22779175.143252

16. Aulton M, Taylor KMG. Aulton's Pharmaceutics 4th Edition.; 2013. doi:10.1016/01683659(89)90050-3

17. Khan A, Iqbal Z, Rehman Z, et al. Application of SeDeM Expert system in formulation development of Effervescent tablets by direct compression. Saudi Pharm J SPJ Off Publ Saudi Pharm Soc. 2014;22(5):433-444. doi:10.1016/j.jsps.2013.07.002

18. Elkhodairy KA, Hassan MA, Afifi SA. Formulation and optimization of orodispersible tablets of flutamide. Saudi Pharm J SPJ Off Publ Saudi Pharm Soc. 2014;22(1):53-61. doi:10.1016/j.jsps.2013.01.009

19. Sarfraz RM, Khan HU, Mahmood A, Ahmad M, Maheen S, Sher M. Formulation and evaluation of mouth disintegrating tablets of atenolol and atorvastatin. Indian $J$ Pharm Sci. 2015;77(1):83-90. doi:10.4103/0250-474x.151602

20. Labib GS. Novel levocetirizine $\mathrm{HCl}$ tablets with enhanced palatability: synergistic effect of combining taste modifiers and effervescence technique. Drug Des Devel Ther. 2015;9:5135-5146. doi:10.2147/DDDT.S92245

21. Aslani A, Beigi M. Design, Formulation, and Physicochemical Evaluation of Montelukast Orally Disintegrating Tablet. Int J Prev Med. 2016;7:120. doi:10.4103/2008-7802.193097 
22. Venkateswarlu K, Nirosha M, Kumar Reddy BK, Sai Kiran BS. Effect of directly compressible excipient and treated agar on drug release of clopidogrel oral disintegrating tablets. Ther Deliv. 2017;8(8):615-624. doi:10.4155/tde-2017-0019

23. Sun $\mathrm{H}$, Wang $X$, Wang J, Shi G, Chen L. Influence of the formula on the properties of a fast dispersible fruit tablet made from mango, Chlorella, and cactus powder. Food Sci Nutr. 2020;8(1):479-488. doi:10.1002/fsn3.1330

24. Olsson H, Mattsson S, Nyström C. Evaluation of the effect of addition of polyethylene glycols of differing molecular weights on the mechanical strength of sodium chloride and sodium bicarbonate tablets. Int $J$ Pharm. 1998. doi:10.1016/S0378-5173(98)00164-1

25. Solaiman A, Suliman AS, Shinde S, Naz S, Elkordy AA. Application of general multilevel factorial design with formulation of fast disintegrating tablets containing croscaremellose sodium and Disintequick MCC-25. Int J Pharm. 2016. doi:10.1016/j.ijpharm.2016.01.06

26. Ziffels S, Steckel $\mathrm{H}$. Influence of amorphous content on compaction behaviour of anhydrous a-lactose. Int J Pharm. 2010. doi:10.1016/j.ijpharm.2009.12.009

27. Wening K, Laukamp EJ, Thommes M, Breitkreutz J. Individual oral therapy with immediate release and Effervescent formulations delivered by the solid dosage pen. J Pers Med. 2012;2(4):217-231. doi:10.3390/jpm2040217

28. Depkes RI. Farmakope Indonesia Edisi IV.; 1995.

29. Romero-de Soto MD, García-Salas P, Fernández-Arroyo S, Segura-Carretero A, Fernández-Campos $\mathrm{F}$, Clares-Naveros $\mathrm{B}$. Antioxidant activity evaluation of new dosage forms as vehicles for dehydrated vegetables. Plant Foods Hum Nutr. 2013;68(2):200-206. doi:10.1007/s11130-013-0346-0

30. Nazir SR, Ambreen G, Irfan HM, Bashir S, Rauf A. Development and formulation of metformin (Antidiabetic) Effervescent Granules: to increase patient compliance and its stability study. Pak J Pharm Sci. 2014;27(4):763-766.

31. Liu Z, Sun X, Liang T, et al. Preparation and Characterization of the Biological Compound Effervescent Granule of Calcium Acetate. Curr Pharm Biotechnol. 2019;20(11):934-944. doi:10.2174/1389201020666190628144637

32. Tajmim A, Siddique AB, El Sayed K. Optimization of Taste-Masked (-)-Oleocanthal Effervescent Formulation with Potent Breast Cancer Progression and Recurrence Suppressive Activities.

Pharmaceutics. 2019;11(10). doi:10.3390/pharmaceutics11100515 
33. Karatzas AA, Politis SN, Rekkas DM. Development of rapidly dissolving pellets within the Quality by Design approach. Drug Dev Ind Pharm. 2017;43(5):770-779. doi:10.1080/03639045.2016.1220576

34. Khan HU, Hanif M, Sarfraz RM, et al. Development and evaluation of novel antihypertensive orodispersible tablets. Pak J Pharm Sci. 2017;30(5):1557-1565. 